3. Planchard D, Popat S, Kerr K, Novello S, Smit EF, Faivre-Finn C, et al; ESMO Guidelines Committee. Metastatic non-small cell lung cancer: ESMO Clinical Practice Guidelines for diagnosis, treatment and follow-up. Ann Oncol. 2018; 29(Supp 4):iv192-237.

4. Ettinger DS, Wood DE, Aisner DL, Akerley W, Bauman J, Chirieac LR, et al. Non-small cell lung cancer, version 5.2017; NCCN clinical practice guidelines in oncology. J Natl Compr Canc Netw. 2017;15:505-35.

5. Gomez DR, Tang C, Zhang J, Blumenschein GR Jr, Hernandez M, Lee JJ, et al. Local consolidative therapy vs. maintenance therapy or observation for patients with oligometastatic non-small-cell lung cancer: long-term results of a multiinstitutional, phase II, randomized study. J Clin Oncol. 2019;37:1558-65.

6. Hanagiri T, Takenaka M, Oka S, Shigematsu Y, Nagata Y, Shimokawa H, et al. Results of a surgical resection for patients with stage IV non-small-cell lung cancer. Clin Lung Cancer. 2012;13:220-4.

7. Liao Y, Fan X, Wang X. Effects of different metastasis patterns, surgery and other factors on the prognosis of patients with V non-small cell lung cancer: a surveillance, epidemiology, and end results (SEER) linked database analysis. Oncol Lett. 2019;18:581-92.
See Article page 1497.

\section{Commentary: Surgery expanding to stage IV non-small cell lung cancer treatment?!}

\author{
Isabelle Opitz, MD, FEBTS
}

There is an increasing body of evidence that the overall long-term survival of patients with oligometastatic nonsmall cell lung cancer (NSCLC) exceeds survival of patients with stage IV disease if all detectable disease is ablated. ${ }^{1}$ Depending on the definition of oligometastatic disease (OMD) with numbers of metastases between 1 and 5 , the real incidence is not clear and reports range from $16 \%$ to $26 \% .^{2,3}$ The differentiation of this patient group from conventional stage IV patients might be based on a biologically different, more localized state of metastatic disease, but also the fact that advanced radiation techniques, including stereotactic radiotherapy (SABR) and minimal invasive surgery translate into improved disease control. Evidence comes from different randomized controlled trials: in the SABR-Stereotactic Ablative Radiotherapy versus Standard of Care Palliative Treatment in Patients with Oligometastatic Cancers Trial, 18 patients with NSCLC with up to 5 metastases were randomized to SABR or standard of care with a clear advantage for the former in terms of progression free survival. ${ }^{4}$ Moreover, Gomez and colleagues

From the Department of Thoracic Surgery, University Hospital Zurich, Zurich, Switzerland.

Disclosures: Author has nothing to disclose with regard to commercial support.

Received for publication March 9, 2020; revisions received March 9, 2020; accepted for publication March 10, 2020; available ahead of print March 31, 2020.

Address for reprints: Isabelle Opitz, MD, FEBTS, Department of Thoracic Surgery, University Hospital Zurich, Raemistrasse 100, 8091 Zurich, Switzerland (E-mail: isabelle.schmitt-opitz@usz.ch).

J Thorac Cardiovasc Surg 2021;161:1508-9

$0022-5223 / \$ 36.00$

Copyright (c) 2020 by The American Association for Thoracic Surgery

https://doi.org/10.1016/j.jtcvs.2020.03.054
Check for updates

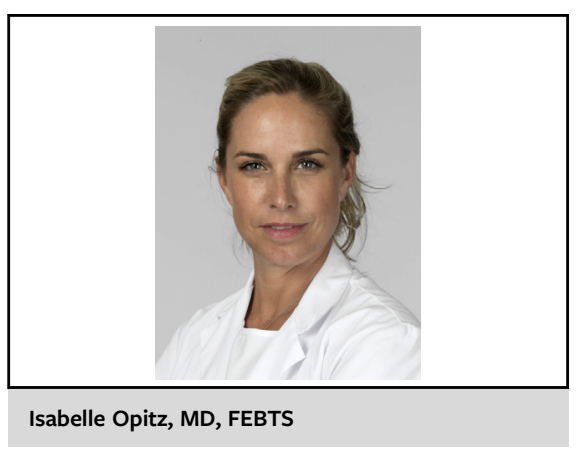

CENTRAL MESSAGE

Durable overall survival rates can be achieved in surgically treated oligometastatic NSCLC.

conducted a phase 2 study in which 49 patients with up to 3 metastases were randomized to maintenance therapy or local consolidative therapy (LCT), including either radiation, SABR, consolidative chemotherapy, or surgery. The trial was closed early because of clear superiority in the treatment arm, with improved progression-free survival and overall survival. ${ }^{5}$ Another phase 2 trial randomized 29 patients with up to 6 metastases to SABR plus maintenance chemotherapy or chemotherapy alone, yielding an increase in progression-free survival. ${ }^{6}$ The role of surgery as a LCT modality in OMD for NSCLC is still unclear because only retrospective, albeit robust, data are available showing improved cancer-specific and overall survival. ${ }^{7-10}$

Mitchell and colleagues ${ }^{11}$ report the retrospective analysis of NSCLC patients with OMD who underwent comprehensive LCT. The mortality rate of $0 \%$ for surgery was associated with a median survival time of 55.2 months compared with 23.4 months after radiotherapy. No 
differences were observed between modalities in site of first failure, cumulative incidence of locoregional failure, or systemic progression. The authors emphasized that these results should be interpreted in the light of a possible selection bias for the patients for comprehensive LCT. This contribution of Mitchell and colleagues ${ }^{11}$ and experts from the MD Anderson Cancer Center Oligometastatic Lung Cancer Working Group further increases the evidence for a role of surgery in patients with stage IV lung cancer with OMD and deserves further investigation in phase 3 clinical trials (as is planned). It will be important for future trials to precisely define OMD and its subclassificationmeta- or synchronous and differentiation from oligo recurrence and oligo progression ${ }^{12}$ - to obtain comparable results and be based on innovative biomarkers aimed at facilitating unbiased treatment allocation, in particular in the evolving field of immunotherapy as a substantial pillar in the treatment of stage IV NSCLC.

\section{References}

1. Hellman S, Weichselbaum RR. Oligometastases. J Clin Oncol. 1995;13:8-10.

2. Xu Q, Zhou F, Liu H, Jiang T, Li X, Xu Y, et al. Consolidative local ablative therapy improves the survival of patients with synchronous oligometastatic NSCLC harboring EGFR activating mutation treated with first-line EGFR-TKIs. J Thorac Oncol. 2018;13:1383-92.

3. Parikh RB, Cronin AM, Kozono DE, Oxnard GR, Mak RH, Jackman DM, et al. Definitive primary therapy in patients presenting with oligometa- static non-small cell lung cancer. Int J Radiat Oncol Biol Phys. 2014 89:880-7.

4. Palma DA, Olson R, Harrow S, Gaede S, Louie AV, Haasbeek C, et al. Stereotactic ablative radiotherapy versus standard of care palliative treatment in patients with oligometastatic cancers (SABR-COMET): a randomised, phase 2, openlabel trial. Lancet. 2019;393:2051-8.

5. Gomez DR, Blumenschein GR Jr, Lee JJ, Hernandez M, Ye R, Camidge DR, et al. Local consolidative therapy versus maintenance therapy or observation for patients with oligometastatic non-small-cell lung cancer without progression after first-line systemic therapy: a multicentre, randomised, controlled, phase 2 study. Lancet Oncol. 2016;17:1672-82.

6. Iyengar P, Wardak Z, Gerber DE, Tumati V, Ahn C, Hughes RS, et al. Consolidative radiotherapy for limited metastatic non-small-cell lung cancer: a phase 2 randomized clinical trial. JAMA Oncol. 2018;4:e173501.

7. Abdel-Rahman O. Outcomes of surgery as part of the management of metastatic non-small-cell lung cancer: a Surveillance, Epidemiology and End Results database analysis. Cancer Invest. 2018:36:238-45.

8. Modi A, Vohra HA, Weeden DF. Does surgery for primary non-small cell lung cancer and cerebral metastasis have any impact on survival? Interact Cardiovasc Thorac Surg. 2009;8:467-73.

9. Tonnies M, Pfannschmidt J, Bauer TT, Kollmeier J, Tonnies S, Kaiser D. Metastasectomy for synchronous solitary non-small cell lung cancer metastases. Ann Thorac Surg. 2014;98:249-56.

10. Opitz I, Patella M, Payrard L, Perentes JY, Inderbitzi R, Gelpke H, et al. Prognostic factors of oligometastatic non-small-cell lung cancer following radical therapy: a multicentre analysis. Eur J Cardiothorac Surg. 2021;161:1497-504.e2.

11. Mitchell KG, Farooqi A, Ludmir EB, Corsini EM, Sepes B, Gomez DR, et al Pulmonary resection is associated with long-term survival and should remain a therapeutic option in oligometastatic lung cancer. J Thorac Cardiovasc Surg. 2021;161:1497-504.e2.

12. Guckenberger M, Lievens Y, Bouma AB, Collette L, Dekker A, deSouza NM et al. Characterisation and classification of oligometastatic disease: a European Society for Radiotherapy and Oncology and European Organisation for Research and Treatment of Cancer consensus recommendation. Lancet Oncol. 2020;21 e18-28. 